\title{
Circulating levels of sialic acid and glycosaminoglycans: a diagnostic test for ankylosing spondylitis
}

\author{
A K SUSHEELA, ${ }^{1}$ TAPOSH K DAS, ${ }^{1}$ JASVIR S KHURANA ${ }^{2}$ A JAYASWAL, ${ }^{2}$ \\ AND P K DAVE \\ From the ${ }^{1}$ Fluoride and Fluorosis Research Laboratories, Department of Anatomy, and the ${ }^{2}$ Department of \\ Orthopaedics, All India Institute of Medical Sciences, New Delhi-110 029, India
}

SUMMARY The circulating levels of sialic acid ( $N$-acetylneuraminic acid) and glycosaminoglycans (GAGs) were measured in 69 patients with spinal disorders of orthopaedic interest (ankylosing spondylitis 17, osteofluorosis 6, idiopathic backache 10, osteoarthrosis 16, osteoporosis 20). The serum GAG levels showed no statistically significant change from control values in the five disorders investigated in the present study. Although osteoporosis and osteoarthrosis showed a decrease in serum sialic acid (SA) levels, the mean ratio (SA/GAG) demonstrated no change from control values. Idiopathic backache showed no difference in any of the parameters studied when compared with control values. Ankylosing spondylitis and osteofluorosis had a remarkable similarity in their clinical and radiological features, but a divergent mean value of ratio was noted. The mean ratio of both the conditions also showed a statistically significant difference from the control value. This suggests that the SA/GAG ratio can be used as a diagnostic test in ankylosing spondylitis.

Key words: osteofluorosis, idiopathic backache, osteoarthrosis, osteoporosis.

Ankylosing spondylitis (AS) is a chronic inflammatory disease affecting mainly the spine and sacroiliac joints, but in some cases arthritic changes occur also in the peripheral joints. ${ }^{1}$ Sacroiliitis has been traditionally regarded as the hallmark of AS. This radiological feature is also seen in other orthopaedic conditions, however. ${ }^{2}$ Erythrocyte sedimentation rate (ESR), acute phase proteins such as $\mathrm{C}$ reactive protein (CRP), and immunoglobulin ( $\operatorname{IgG}, \operatorname{IgA}$ ) concentrations are some of the important laboratory markers of AS. These markers are, however, unreliable diagnostically owing to lack of specificity and poor correlation with disease activity. ${ }^{34} \mathrm{~A}$ very high prevalence of HLA-B27 in patients with AS has been reported by various authors. ${ }^{56}$ All B27 positive individuals do not develop AS, however, and the B27 negative and positive patients of AS demonstrate identical skeletal manifestations. ${ }^{7}$ The asso-

Accepted for publication 10 March 1988.

Correspondence to Dr A K Susheela, Fluoride and Fluorosis Research Laboratories, Department of Anatomy, All India Institute of Medical Sciences, New Delhi-110 029, India. ciation of the B27 antigen with other seronegative arthropathies, such as Reiter's disease ${ }^{8}$ and reactive arthritis after gastrointestinal infection, ${ }^{9}$ further limits the diagnostic relevance of HLA-B27 in AS. As there is no specific diagnostic test for AS, misdiagnosis is not uncommon, especially if the disease begins in the peripheral joints or with iritis or aortitis. ${ }^{10}$

Proteoglycans and sialoprotein are the two significant components in mineralised bone matrix. ${ }^{11}$ These matrix components are known to be important for the maintenance of bone structure and calcification. It is thus to be expected that bone disorders would bring about a change in their contents.

Bone biopsy procedures for quantitative analysis of proteoglycans (GAGs) and sialoprotein (SA), though possible, are not a practical solution as patients invariably refuse biopsy. Therefore the circulating levels of sialic acid and GAGs in different orthopaedic disorders have been evaluated. $\bar{R}$ aised values of serum SA ( $N$-acetylneuraminic acid) have been reported in osteoarticular tuberculosis, ${ }^{12}$ chronic osteomyelitis, ${ }^{13}$ and rheumatoid arthritis. ${ }^{14}$ 
Increased circulating levels of GAGs were demonstrated in patients with rheumatoid arthritis ${ }^{15}$ and in inflammatory conditions secondary to bacterial infection or traumatic injuries. ${ }^{16}$

These increases in SA and GAGs, however, had very little diagnostic significance when studied separately because the same pattern of change was noted in more than one condition. SA and GAGs have also been studied in bone metabolism relating to fluoride toxicity. For the first time the SA/GAG ratio was applied as a diagnostic test in osteofluorosis to assess the onset of toxic manifestations in bone as a result of excess ingestion of fluoride. ${ }^{17} \mathrm{~A}$ significant correlation was noted between the ratio SA/ GAG and osteofluorosis when compared with normal values. The mean ratio was reduced to $30-50 \%$ in fluoride toxicity. ${ }^{17}$

It is in this context that the present study was undertaken to investigate whether the ratio of SA to GAG could be of diagnostic importance in other orthopaedic disorders.

\section{Patients and methods}

Cases were selected from orthopaedic outpatient clinics and from inpatients at the All India Institute of Medical Sciences, New Delhi. In each case a detailed clinical examination and careful radiological examination were done and the diagnosis confirmed. Five different types of bone disorders were chosen. Table 1 shows details of the cases investigated. The control group consisted of 10 healthy individuals selected from students, laboratory workers, and resident doctors (Table 1) Blood $(5.0 \mathrm{ml})$ was obtained from each individual and serum samples were stored at $-20^{\circ} \mathrm{C}$. Sialic acid and GAG estimations were done within 48 hours.

\section{ESTIMATION OF SIALIC ACID}

Serum sialic acid was estimated according to Winzler $^{18}$ with $N$-acetylneuraminic acid (Sigma, USA) as standard. A $4.80 \mathrm{ml}$ aliquot of $5.0 \%$ trichloroacetic acid was added to $0.2 \mathrm{ml}$ of serum in capped test tubes and placed in a boiling water bat for 15 minutes. After cooling in ice cold water the samples were centrifuged at $1500 \mathrm{rpm}$ for 15 . minutes. Aliquots of the supernatant were used fow colour development with diphenylamine reagent (1 $\mathrm{g}$ diphenylamine in $90 \mathrm{ml}$ glacial acetio acid $+10 \mathrm{ml}$ concentrated $\mathrm{H}_{2} \mathrm{SO}_{4}$ ). Correction forp non-specific colour development was applied. Opti\$ cal density was read on a Spectronic-200@ spectrophotometer at $530 \mathrm{~nm}$. The results were expressed as $\mathrm{mg} / \mathrm{l}$.

ESTIMATION OF GLYCOSAMINOGLYCANS GAGs in sera were estimated according tô Whiteman. ${ }^{19}$ To a known amount of serum $(20 \mu \mathrm{l})$ i small disposable plastic tubes, $1.0 \mathrm{ml}$ alcian bluस reagent $(0.05 \% \mathrm{w} / \mathrm{v}$ alcian blue $8 \mathrm{GX}$ and $50 \mathrm{mM}$ $\mathrm{MgCl}_{2}$ in $50 \mathrm{mM} \mathrm{CH} \mathrm{CHONa}_{3} \mathrm{COdjusted} \mathrm{to} \mathrm{pH} 5.80$ with acetic acid) was added. The GAG-alcian blues complex (precipitate) was allowed to settle for fouf to six hours and separated by centrifugation at $200 \theta$ $\mathrm{rpm}$ for 15 minutes. The precipitate was washe with $2.0 \mathrm{ml}$ ethanol and dissociated with $1.0 \mathrm{ml}$ manêे axol IB reagent $(40 \% \mathrm{w} / \mathrm{v}$ manaxol IB in $50 \mathrm{nN}$ sodium acetate buffer, pH 5.8) The clear solution. was read at $620 \mathrm{~nm}$ in a Spectronic-2000 spector 000 photometer. Chondroitin sulphate (from sherrR cartilage, Koch light) was used as standard. \$ुj results were expressed as $\mathrm{mg} / \mathrm{l}$.

STATISTICAL METHOD
The significance of the difference between the mea⿳亠丷厂 values was estimated by Student's $t$ test.

\section{Results}

CONTROL GROUP

Eight men and two women aged 23-55 years (mea (SD) $32.9(11)$ ) were studied. Their serum sialic aciō concentrations ranged from 648.0 to $812.7 \mathrm{mg} /$ (mean (SD) $722.2(67 \cdot 1)$ ) and their GAG concentrations from 165.0 to $225.0 \mathrm{mg} / \mathrm{l}$ (mean (SD) 194.6 $(18 \cdot 4))$. The ratio SA/GAG ranged from 3.0 to 3.97 (mean (SD) $3.73(0.42)$ ) (Table 2, Fig. 1).

Table 1 Details of cases investigated

\begin{tabular}{|c|c|c|c|c|c|}
\hline \multirow[t]{2}{*}{ Condition } & \multicolumn{3}{|c|}{ Number of cases } & \multirow{2}{*}{$\begin{array}{l}\text { Age range } \\
\text { (years) }\end{array}$} & \multirow{2}{*}{ 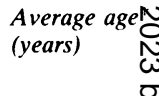 } \\
\hline & Male & Female & Total & & \\
\hline Control & 8 & 2 & 10 & $23-55$ & 32.9 (11) ع \\
\hline Osteofluorosis & 4 & 2 & 6 & $19-60$ & $37 \cdot 3(15)$ \\
\hline Ankylosing spondylitis & 16 & 1 & 17 & $16-50$ & 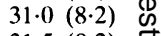 \\
\hline Idiopathic backache & 8 & 2 & 10 & $18-40$ & $31.5(8.2)$ \\
\hline Osteoarthrosis & 4 & 12 & 16 & $40-60$ & $50 \cdot 0(6 \cdot 0)$ \\
\hline Osteoporosis & 1 & 19 & 20 & $32-70$ & $53.0(11.9) \stackrel{ }{\circ}$ \\
\hline
\end{tabular}


Table 2 Results for sialic acid (SA), glycosaminoglycans (GAGs), and SA/GAG in the six groups investigated. Values are means $(S D)$

\begin{tabular}{|c|c|c|c|c|}
\hline Condition & $\begin{array}{l}\text { Sialic acid } \\
(m g / l)\end{array}$ & $\begin{array}{l}\text { Glycosaminoglycans } \\
(\mathrm{mg} / \mathrm{l})\end{array}$ & $S A / G A G$ & $\begin{array}{l}\text { SA/GAG } \\
\text { range }\end{array}$ \\
\hline Control & $722 \cdot 2(67 \cdot 1)$ & $194 \cdot 6(18 \cdot 4)$ & $3.73(0.42)$ & $3.0-3.97$ \\
\hline Osteofluorosis & $484.5(77.4)^{*}$ & $206 \cdot 8(43 \cdot 7)$ & $2.36(0.24)^{*}$ & $1 \cdot 91-2 \cdot 58$ \\
\hline Ankylosing spondylitis & $895.9(183.9)^{* *}$ & $197.9(34.4)$ & $4.58(0.95)^{* *}$ & $3 \cdot 72-6 \cdot 32$ \\
\hline Idiopathic backache & $613.4(159 \cdot 3)$ & $181 \cdot 5(28 \cdot 6)$ & $3.45(1.03)$ & $2 \cdot 35-4 \cdot 75$ \\
\hline Osteoarthrosis & $568.2(73.8)^{*}$ & $165.2(58.9)$ & $3.9(1.55)$ & $1 \cdot 61-7 \cdot 47$ \\
\hline Osteoporosis & $597.0(91.9)^{*}$ & $185.8(61.8)$ & $3.67(1.61)$ & $1.71-7.47$ \\
\hline
\end{tabular}

${ }^{*} \mathrm{p}<0.001 ;{ }^{* *} \mathrm{p}<0.01$.

\section{ANKYLOSING SPONDYLITIS}

Seventeen patients (16 male, one female) with ages ranging from 16 to 50 years (mean (SD) $31(8 \cdot 2)$ ) were studied. Table 2 shows that the sialic acid concentration in serum inçreased $(p<0 \cdot 01)$, whereas the GAG content showed no significant difference from the control values. For the ratio SA/GAG a significant increase was noted $(\mathrm{p}<0.01)$ (Table 2, Fig. 1).

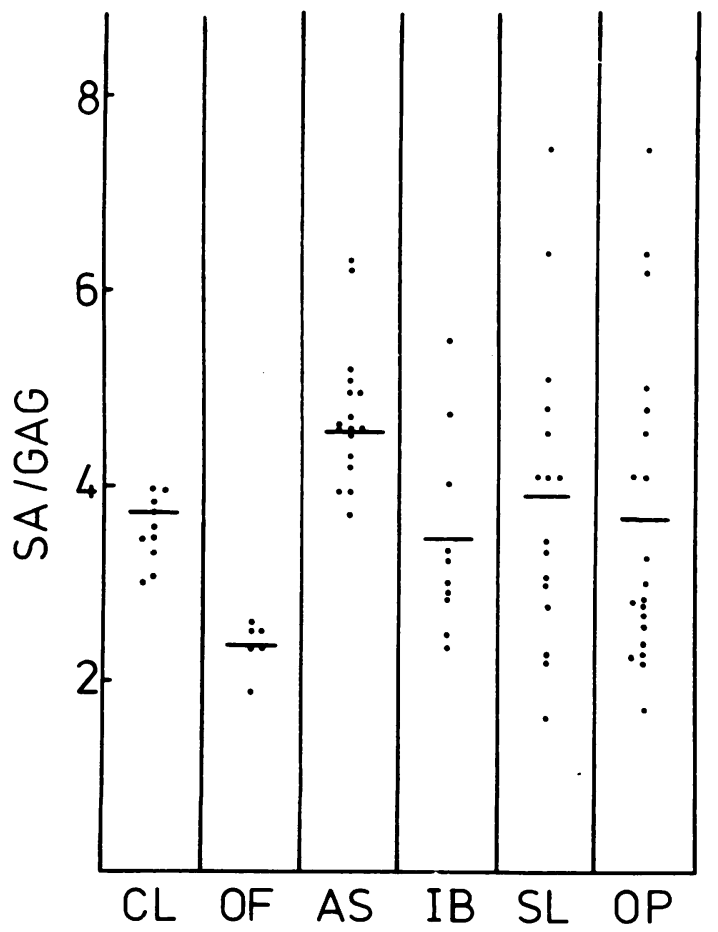

Fig. $1 S A / G A G$ ratio distribution in $C L=$ control $(n=10)$; $O F=$ osteofluorosis $(n=6) ; A S=$ ankylosing spondylitis $(n=17) ; I B=$ idiopathic backache $(n=10)$;

$S L=$ osteoarthrosis $(n=16) ; O P=$ osteoporosis $(n=20)$. The horizontal bars show the mean for each group.

\section{OSTEOPOROSIS}

Twenty patients (19 female, one male) with ages ranging from 32 to 70 years (mean (SD) 53 (11.9)) were studied. The serum sialic acid concentration showed a significant decrease $(p<0 \cdot 001)$, but the GAG concentration and the ratio SA/GAG showed no statistically significant change from control values (Table 2, Fig. 1).

\section{OSTEOARTHROS IS}

Sixteen patients (four male, 12 female) were included in this group. Their ages ranged from 40 to 60 years (mean (SD) 50.0 (6.0)). A significant decrease in serum sialic acid concentration was observed $(\mathrm{p}<0.001)$. The GAG concentration showed a slight decrease, but the difference was not statistically significant. The ratio of SA to GAG remained unaltered (Table 2, Fig. 1).

IDIOPATHIC BACKACHE

Ten patients were studied (eight male, two female) with ages ranging from 18 to 40 years (mean (SD) $31 \cdot 5(8 \cdot 2)$ ). The sialic acid and GAG concentrations in serum showed no statistically significant difference, and the ratio SA/GAG was also unchanged when compared with control values (Table 2, Fig. 1).

\section{OSTEOFLUOROSIS}

Six patients (four male, two female) with ages ranging from 19 to 60 years (mean (SD) 37.3 (15)) were studied. The sialic acid content in serum decreased, whereas the GAG concentration was slightly increased. The decrease in sialic acid concentration was significant $(p<0 \cdot 001)$, but the increase in the concentration of GAG was not statisically significant. The ratio of SA to GAG showed a highly significant decrease $(p<0.001)$ when compared with the control value (Table 2, Fig. 1).

\section{Discussion}

Bone, being one of the most highly mineralised and 
complex tissues in the body, is poorly understood in several aspects. The spectrum of non-collagenous proteins within the mineralised bone indicates that these molecules are necessary for matrix structure and mineralisation. ${ }^{20}$

Sialoprotein (sialic acid) and proteoglycans (GAGs) are two very significant non-collagenous proteins of bone. ${ }^{21} \mathrm{~A}$ large portion of non-collagenous protein in developing bone is serum derived proteins, ${ }^{22-24}$ which indicates that these proteins are freely diffusing in the vicinity of the mineralisation front. ${ }^{21}$ Thus a link between serum proteins and non-collagenous proteins of bone is expected. It is in this context that the present study of sialic acid and GAGs was undertaken in serum.

An increase in serum sialic acid content was observed in AS, whereas in other bone diseases investigated (osteofluorosis, osteoarthrosis, osteoporosis) a decrease was noted compared with control values (Table 2). Ninety per cent of sialic acid in normal sera is bound to $\alpha$ and $\beta$ globulins, and these fractions of serum protein are known to increase in inflammatory conditions. ${ }^{12}$ This, therefore, may be one of the reasons for enhanced serum sialic acid concentrations in AS.

The ESR is known to increase in inflammatory conditions, but in AS its relation with disease activity and duration of illness is in dispute. Blumberg and Regan found high ESR values in early stages of spondylitis but more normal values with longer disease duration. ${ }^{25}$ Kendall et al reported no correlation between ESR and disease activity as assessed by pain scale. ${ }^{26}$ Although in the present investigation raised values were found in 10 out of the 13 cases of AS investigated for ESR, the increase was not specific as $50 \%$ of the patients with osteoporosis and osteoarthrosis also showed an increased ESR, thus establishing the fact that ESR is diagnostically unspecific for AS. (As a routine clinical test the ESR was investigated by the clinical pathology laboratory at the All India Institute of Medical Sciences in the same series of patients and it was observed that 10 cases of AS out of 13 , eight cases of osteoporosis out of 16 and six cases of osteoarthrosis out of 12 had raised ESR (ESR normal value $\leqslant 20 \mathrm{~mm} / 1 \mathrm{st} \mathrm{h}$ ).

Patients with osteofluorosis and osteoporosis present divergent radiological manifestations, but both the groups, interestingly, show a similar decrease in their circulating levels of sialic acid (Table 2). The results suggest that possibly a common biochemical pathology is involved in these two conditions. A similar decrease in sialic acid is also noted in patients with osteoarthrosis. The reduction in sialic acid concentrations observed may be due to either a decrease in the biosynthesis or the protein synthesis may itself get disturbed, resulting in low circulating levels of protein bound carbohydrate. ${ }^{27}$

Unlike sialic acid, serum GAG concentrations show no significant alteration from control valueso except for a slight increase in osteofluorosis and $\Phi$ slight decrease in osteoarthrosis (Table 2). The reason for this is not evident, though it may possible be due to the fact that the percentage of GAGs pre $\mathbb{\infty}$ sent in bone is far less than the sialic acid fraction $^{28}{ }^{29}$ or that the GAGs are degraded and

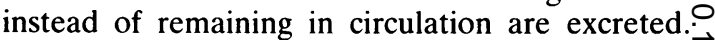

Jha et al in a study on fluoride toxicity and fluorosis established a diagnostic test fo雨 osteofluorosis using the SA to GAG ratio. ${ }^{17}$ Th" same test was applied to five different orthopaedia disorders, including osteofluorosis.

It is an established fact that in idiopathic backach $\vec{尺}$ neither the clinical nor the radiological presentace tions are different from those of normal subjects $\mathrm{s}_{0}$ The results obtained from the present study als $\bar{\Theta}$ confirm the view that there is no significant chang $\vec{\delta}$ between idiopathic backache and normal subjectss Although patients with osteoporosis and osteoo arthrosis showed a decrease in their circulating levels of sialic acid, no difference was noted in theid mean SA/GAG ratio (Fig. 1, Table 2).

A $37 \%$ decrease in the mean ratio of $\mathrm{SA} / \mathrm{G}$ was noted in osteofluorosis when compared wtot control values. This is in agreement with a previous study. ${ }^{17}$

Ankylosing spondylitis and osteofluorosis havहैँ similar radiological presentations and clinically to 8 the two conditions are somewhat similar, ${ }^{30}$ but the mean ratio of SA/GAG was found to be nearl? double that for osteofluorosis. The mean ratio in ankylosing spondylitis was also significantly dif ferent $(p<0.01)$ from the control value (Table $2 \frac{\mathrm{N}}{3}$ Fig. 1).

The SA/GAG ratio for the 17 patients wit ankylosing spondylitis and the six with osteofluoro: sis matched with the data for 10 controls shown i⿱日一) the scattergram (Fig. 1) proves the precision and validity of the test. Ankylosing spondylitis may be undiagnosed or misdiagnosed because the clinica features vary considerably. ${ }^{31}$ An increase in ESR $\mathrm{CRP}$, and immunoglobulin concentrations an haematological changes like thrombocytosis and leucocytosis, though found to be associated with ankylosing spondylitis, are also noted in othef inflammatory rheumatic diseases, ${ }^{34}$ rendering the above test unspecific. Considering the above fact our findings are encouraging and the SA/GAG rati\$ is recommended as a diagnostic test for AS.

We wish to thank Mr Kamal Sharma of the Fluoride and Fluoros Research Laboratory for his help in experimental procedures an for statistical analysis of the data. The help of Mr B Saha, wh 
typed the manuscript, is greatly acknowledged. This study was supported by grants-in-aid to AKS received from the Department of the Environment, Ministry of Environment and Forests, Govt of India; Department of Science and Technology, Govt of India; and the Technology Mission on Safe Drinking Water, Govt of India.

\section{References}

1 West H F. The aetiology of ankylosing spondylitis. Ann Rheum Dis 1949; 8: 143-8.

2 Dixon A S, Lience E. The sacro-iliac joints in adult rheumatoid arthritis and psoriatic arthropathy. Ann Rheum Dis 1961; 20: 247-57.

3 Shettan N J, Slavin B M, Donoxon M P, Mount J N, Mathews J A. Lack of correlation between clinical disease activity and erythrocyte sedimentation rate, acute phase proteins or protease inhibitors in ankylosing spondylitis. Br J Rheumatol 1986; 25: $171-4$

4 Sanders K M, Hertzman A, Escobar M R, Littman B H. Correlation of immunoglobulin and $C$ reactive protein levels in ankylosing spondylitis and rheumatoid arthritis. Ann Rheum Dis 1987; 46: 273-6.

5 Brewerton D A, Hart F D, Nicholls A, Caffrey M, James D C O, Sturrock R D. Ankylosing spondylitis and HL-A27. Lancet 1973; i: 904-7.

6 Schlosstein L, Terasaki P I, Bluestone R, Pearson C M. High association of an HLA antigen, W27 with ankylosing spondylitis. $N$ Engl $J$ Med 1973; 288: 704-6.

7 Khan M A, Kushner I, Braun W E. Comparison of clinical features in HLA-B27 positive and negative patients with ankylosing spondylitis. Arthritis Rheum 1977; 20: 909-12.

8 Woodrow J C. Histocompatibility antigens and rheumatic diseases. Semin Arthritis Rheum 1977; 6: 257-76.

9 Aho K, Ahvonen P, Alkio P, et al. HL-A27 in reactive arthritis following infection. Ann Rheum Dis 1975; 34 [suppl 1]: 29-30.

10 Calabro J J, Mody R E. Management of ankylosing spondylitis. Bull Rheum Dis 1966; 16: 408-11.

11 Linde A, Jontell M, Lundgren T, Nilson B, Svanberg U. Noncollagenous proteins of rat compact bone. J Biol Chem 1983; 258: $1698-705$.

12 Carter A, Martin N H. Serum sialic acid levels in health and disease. J Clin Pathol 1962; 15: 69-72.

13 Gupta A K, Sur B K, Taneja D K. Serum sialic acid in different bone disorders. J Indian Med Assoc 1973; 60: 87-9.

14 Omdal R, Aurebekk B. Sialic acid (N-acetyl neuraminic acid) in the synovial fluid and serum of patients with inflammatory and non-inflammatory joint disease. Scand J Rheumatol 1985; 14: $87-9$.
15 Badin J, Schubbert M, Vouras M. Plasma polysaccharides fraction containing uronic acid in normal subjects and in patients with rheumatoid arthritis. J Clin Invest 1955; 34: 1317-23.

16 Kerby G P. The effect of inflammation on hexuronate containing polysaccharide of human plasma. J Clin Invest 1958; 37: 962-4.

17 Jha M, Susheela A K, Krishna N, Rajyalakshmi K, Venkiah K. Excessive ingestion of fluoride and the significance of sialic acid upon glycosaminoglycans in the serum of rabbit and human subjects. J Toxicol Clin Toxicol 1982; 19: 1023-30.

18 Winzler R J. In: Davi G, ed. Methods in biochemical analysis. Vol 2. New York: Interscience, 1961: 298.

19 Whiteman P. The quantitative measurement of alcian blueGAG complexes. Biochem $J$ 1973; 131: 343-50.

20 Urist M R. Biochemistry of calcification. In: Bourne G H, ed. Biochemistry and physiology of bone. New York: Academic Press, 1976: 1-59.

21 Fisher L W, Termine J D. Non-collagenous proteins influencing the local mechanisms of calcification. Clin Orthop 1985; 200: 363-85.

22 Owen M, Triffitt J T, Melick R A. Albumin in bone. In: Hard tissue growth repair and remineralization. Amsterdam: Excerpta Medica, 1973: 263-93. (Ciba Foundation Symposium, No 11.)

23 Ashton B A, Triffitt J T, Herring G M. The isolation and partial characterization of two glycoproteins from bovine cortical bone. Eur J Biochem 1974; 45: 525-33.

24 Triffitt J T, Owen M E, Ashton B A, Wilson J M. Plasma disappearance of rabbit Hs-glycoprotein and its uptake by bone tissue. Calcified Tissue Research 1978; 26: 155-61.

25 Blumberg B, Ragan C. The natural history of rheumatoid spondylitis. Medicine (Baltimore) 1956; 35: 1-31.

26 Kendall M J, Lawrence D S, Shuttleworth G R, Whitfield A G W. Haematology and biochemistry of ankylosing spondylitis. $\mathrm{Br}$ Med J. 1973; ii: 235-7.

27 Susheela A K, Sharma Y D. Jha M, Rajyalakshmi K, Rama M, Rao N Y. The chemical profile of human serum in fluoride toxicity and fluorosis I. Total protein bound carbohydrate seromucoid and fluoride levels. Fluoride 1981; 14: 150-4.

28 Termine J D, Belcourt A B, Conn K M, Kleinmann H K. Mineral and collagen binding proteins of female calf-bone. J Biol Chem 1981; 256: 10403-8.

29 Fisher L W, Whitson S W, Avioli L V, Termine J D. Matrix sialoprotein of developing bone. J Biol Chem 1983; 258: 12723-7.

30 Fourman P, Royer P. Calcium metabolism and the bone. 2nd ed. Oxford: Blackwell, 1968.

31 Anonymous. Spondylitis: time for a new name and a new approach to diagnosis [Editorial]. Lancet 1985; ii: 479-81. 